\title{
How long will business as usual be sustained?
}

Dandy, Norman

\section{Environmental Values}

DOI:

$10.3197 / 096327121 X 16141642287610$

Published: 01/04/2021

Publisher's PDF, also known as Version of record

Cyswllt i'r cyhoeddiad / Link to publication

Dyfyniad o'r fersiwn a gyhoeddwyd / Citation for published version (APA):

Dandy, N. (2021). How long will business as usual be sustained? Environmental Values, 30(2), 141-146. https://doi.org/10.3197/096327121X16141642287610

\footnotetext{
Hawliau Cyffredinol / General rights

Copyright and moral rights for the publications made accessible in the public portal are retained by the authors and/or other copyright owners and it is a condition of accessing publications that users recognise and abide by the legal requirements associated with these rights.

- Users may download and print one copy of any publication from the public portal for the purpose of private study or research.

- You may not further distribute the material or use it for any profit-making activity or commercial gain

- You may freely distribute the URL identifying the publication in the public portal ?
}

Take down policy

If you believe that this document breaches copyright please contact us providing details, and we will remove access to the work immediately and investigate your claim. 


\section{How Long Will Business as Usual Be Sustained?}

Two of the earliest and most intuitive themes I encountered in my studies of environmental politics, sociology and philosophy were the enduring power of mainstream ideas and values, and the related debate about whether humanity could achieve sustainability via reform of our anthropocentric lives and economies, or whether we needed radical change. In essence, could 'business as usual' be sustainable? The scholarly limits of these rather blunt framings have long been noted (e.g. Barry 1994), and there have been ongoing calls for greater differentiation and clarity between supposedly distinct positions, not least within the pages of this journal (e.g. Schoppek 2020). However, as we drive deeper into the so-called Anthropocene (Baskin 2015) these themes still permeate much environmental scholarship and debate.

There are a wide range of examples of how reform dominates more radical (i.e. fundamental) change. Many actors within the farming and food system are working to produce meat more sustainably in an attempt to avoid the shift towards widespread adoption of plant-based diets. Meaningful dietary change is, however, marginalised by the dominant values and practices of industrial meat production and consumption that so deeply permeate the everyday lives and cultures of billions of humans (Pollan 2006). In the process animals are reduced to mere commodities and quantitative units (Nordgren 2012; Kortetmäki 2019). The promise of new automotive technologies is that they will enable millions to maintain their hyper-mobile, global lifestyles. The idea of radically reorienting work and recreation towards the local is side-lined. Individual recognition of the environmental impacts of car use continues to be undermined by the promotion of the increasingly ubiquitous preferences and presumptions of 'car culture' (Paterson 2000; 2007) - perpetually reinforced by global capital - that cast personal mobility as an essential, immutable aspect of everyday life (Aasen and Vatn 2020).

In contrast, as recent editorials in Environmental Values have noted, the coronavirus pandemic has had a particularly radical impact on lives across the globe. It has disrupted countless established routines, ideas, practices, habits and customs. It has also brought about rapid radical changes in practice. The long-term effects, however, remain to be seen. The potential is for it to constitute a 'reset' - opening up new possibilities for more sustainable living and working, reconnecting people with the 'local' (built and 'natural' places alike), enabling reflection on entrenched habits and practices, and facilitating expressions of alternative values. However, the interests alluded to above will aim to prevent this. The pandemic would then transpire simply to be an opportunity for global capital and corporations to reform and renew their hegemony through rapidly tying consumers in to new forms and structures of commodification, such as 'smart' technologies for promoting individualised, home based consumption (Spash 2020a). The reality is likely, of course, to be

Environmental Values 30 (2), April 2021: 141-146.

(C) 2021 The White Horse Press. doi: 10.3197/096327121X16141642287610 


\section{EDITORIAL}

highly heterogeneous and hybridised across different sectors of global society. Demand for radical change may become louder, dragging established interests towards them whilst those same corporate interests hastily seek ways in which to remodel those demands and satisfy them with redesigned and new products. In this struggle the sustainability of new practices - such as remote working and internet shopping - cannot be assumed simply because they avoid (or displace) practices known to be unsustainable.

The diverse contributions to this issue of Environmental Values speak to these long-standing themes in a number of ways that are reminiscent of the debates over 'weak' vs 'strong' sustainability, and highlight the resilience of human exceptionalism and mainstream anthropocentric values. The presumed inexhaustible promise of science and faith in technological solutions has remained firmly in place. The primacy of reformist approaches is evident in the first three papers of this issues despite their diverse topics - oil production, the bio-based economy and film production.

Marianne Takle lays out the development of the Norwegian Petroleum Fund and its configuration of obligations and commitments to future generations. Through documentary analysis, Takle identifies four phases of the fund's development since its foundations were laid in the early 1970s. She maps the shifting justifications and political architecture of the fund, which is now under the name of the Norwegian Government Pension Fund Global. Valued at well over US\$ 1 trillion, it is now the world's largest sovereign wealth fund. This value is twice the national GDP, corresponds to around US\$200,000 per Norwegian, and in recent years fund revenues have themselves exceeded actual petroleum revenues. Takle asks, however, whether this extraordinary financial wealth really represents the best value for future Norwegians? As the full consequences of climate change are realised, future generations of Norwegians might find themselves wishing their ancestors had left the oil and gas in the seabed.

At the outset of Norwegian oil production in the early 1970s key actors emphasised the need to ensure that economic growth based on resource extraction did not cause environmental harm. Gradually, however, as oil and gas resources were extracted and the capital transformed from natural to financial, so the associated discourse transformed from ecological to economic. Takle shows how the concepts of weak sustainability and value commensurability have come to dominate related public policy. So much so that via explicit reference to 'savings' for future generations, the fund's existence actually facilitates the claim that the extraction of fossil fuels is a moral good - a way of raising the future welfare of Norwegians. Business as usual is promoted over impending climate catastrophe.

In their contribution, Veraat and Blok contribute a philosophical analysis of some of the fundamental concepts and components of the bio-based economy - an important strand of global responses to the sustainability crisis. The 
authors highlight the conceptual ambiguities and inconsistencies of the biobased economy and set it in relation to other associated phenomena - such as the circular economy, life cycle assessment and biomimicry - which have each received attention within this journal (Nordgren 2012; Korhonen et al 2018; Dicks 2019; Zwart 2019). It is argued that each of these has the common goal of closing material cycles, thus mirroring the circularity of natural biospheric phenomena such as ecosystems and energy cycles. To this end bio-based economies look to develop and employ processes that maintain energy levels, convert waste into valuable products and replace non-renewable resources.

The authors then deploy the works of Emmanuel Levinas and Nicholas Georgescu-Roegen to provide the foundations of a more developed understanding of the heterogenous relationship between economy and ecology. In particular, Levinas' ideas are used to assert the human necessity to overcome the 'hostile' natural world via 'trade, labour and housing' and thus articulate the impossibility of a truly eco-centric perspective emanating from necessarily anthropocentric human beings. There are clear echoes of Takle's analysis as the dominance of existing paradigms is again highlighted. They identify the weak sustainability of prevalent types of bio-based economy and identify 'a presupposed, univocal dominance of economic processes over ecological boundaries'. Bio-based economic practices remain a 'side event' outside of the core business for most companies: at best 'a new way of doing business-as-usual'.

The dominance of 'business as usual' is also a significant concern for Hunter Vaughan in his analysis of the sustainability of media productions. He notes the intimate relationship between productions and their resource contexts, and identifies the profound environmental impacts of established studios and mobile productions. Reflection on the sustainability of the media industry is especially timely given the enormous growth of home entertainment within wealthier societies that has come into its own so effectively during 'lockdown'. The comfortable consumption of these audio-visual products in the home is so far abstracted from any negative environmental and socio-cultural impacts that they may have as to make recognition and understanding of them extremely challenging. In recent years, the media industry has become 'an instrumental purveyor of green rhetoric' and ostensibly sought to reform its practices in a quest for sustainability. Vaughan considers much of this to be 'greenwash'. Minor behavioural and resource use reforms obscure the avoidance of the fundamental changes to the business model required to mitigate substantial environmental and climate change.

The author reviews the political economy and impacts of mobile productions. This model moves outside the studio and into non-permanent production spaces which possess, critically, pre-existing cultural and environmental qualities. Usually this is done to take advantage of appropriate locations and landscapes, but often also capitalises on reduced costs, low wages, tax credits and other subsidies. Vaughan advances the fascinating idea that these mobile 


\section{EDITORIAL}

productions can be understood as invasive species - a non-native 'organism' that harms the local environmental, economic and socio-cultural systems. The analysis unpicks the Michigan Film and Digital Media Incentive that aimed to grow the US state's economy and communicate a suite of particular environmental and other values via the encouragement of film and television production. Mobile productions in the marine environment of south Florida are also within the analytic viewfinder. The author notes the long tradition of underwater cinematography in the region, which offers excellent environmental and light conditions, and features considerable important and sensitive marine habitat. A number of studios are becoming increasingly cognizant of local knowledge, ecology and values. Vaughan notes that with 'bigger memory and smaller equipment' production practices have improved. However, for many bigger productions 'it remains business as usual, with vast fleets of motorboats, copious use of fuel and unbridled disturbance to the local ecosystem.'

The two other contributions to this issue of Environmental Values shift away from applied analyses to theoretical work in relation to the Anthropocene concept. Arianne Conty reflects on the potential contributions of Christianity and animism to addressing the challenges presented by the Anthropocene. She reviews the broad range of contemporary Christian responses to the environmental crises that have emerged over the last two decades. These reach back to St Francis of Assisi and his acknowledgement of the breadth of God's human and non-human creation. However, Conty highlights positions advocated by a number of contemporary Christian thinkers within both apologetic and sacramental traditions. Whilst the apologetic tradition focuses on stewardship of nature, the sacramental position rejects this as overly anthropocentric. Instead it focuses on the 'sacred quality of the universe' and removes humans from the pedestal of an exclusive relationship with God. This, it is argued, generates a more ecologically democratic, multispecies set of relations. However, in an echo of this issue's earlier contributions that sounds something like theological 'business as usual', Conty notes that prominent scholars expounding a sacramental perspective have been 'defrocked' and 'pushed to the periphery'. Consequently they lack the authority and resources that could underpin effective change.

Conty then moves on to consider the (re)emergence of animism as a system that may provide a stronger set of beliefs more appropriate to the Anthropocene. The focus here is on 'seeing, feeling and thinking as another' - the ability to consider multiple points of view and put oneself in the place of others, including other species. This anthropomorphism, empathy and kinship within animist traditions is cast as an antidote to Christian anthropocentrism. This leads the author towards two perhaps surprising conclusions. In answer to her own question as to whether we need to 'prepare darts for a blowgun and set up camp in a Yurt' to 're-become indigenous', Conty identifies study of the 
humanities and, specifically, reading as crucial tools for the required 'ontological boundary crossing' similar to animism.

Patryk Szaj maintains our focus on the Anthropocene concept with consideration of the potential contribution of Hans-Georg Gadamer's hermeneutics to our articulation of it. Gadamer's central work, Truth and Method (1960), was written during the post war 'Great Acceleration' that some scholars identify as the Anthropocene's baseline (Baskin 2015). However, two of his later essays (published in 1972 and 1985) contain evidence of an early recognition of the conditions characteristic of this supposed new geological era. In particular Gadamer observed that the post-war practices underpinning the subjugation of nature were fundamentally different from previous practices, notably having transformed from entailing generally local impacts, to having impacts felt globally. These novel practices emerged from the dominant paradigm of human exceptionalism, itself a remnant of prevailing theology and were founded on an unbridled faith in science and unrestrained 'technocratic unscrupulousness'. Gadamer noted there was a consequent need to 'demythologise science' and reign in beliefs that technical solutions are available to every environmental challenge

Weak forms of sustainability abound, from 'moral' justifications for fossil fuel extraction based on financial values to dominant theological traditions to continued human exceptionalism. Despite many decades of evidence and thought relating to environmental degradation and its myriad costs, it appears that minor adjustments to dominant ideas and practices are still the norm across much of global society. Having said that, the global coronavirus pandemic has devastated many lives, and the cracks in established dominant ways of living are all too apparent. Arguably the need for critical thinking and effective conceptual, policy and environmental management tools, such as those presented in this journal and others, has never been greater as the opportunities for change presented by this crisis emerge. We need ready ways to restructure relations between humans and non-humans, ways to engage with the 'local', and ways to pivot away from dominant capitalist economic systems towards more social and ecologically just approaches (Spash 2020b). There will also be increasingly loud calls for ways to re-strengthen and re-invigorate community and social capital in the wake of the 'social distancing' that is blighting the everyday existence of millions. How long will 'business as usual' be sustained?

NORMAN DANDY Bangor University 


\section{EDITORIAL}

\section{REFERENCES}

Aasen, M. and Vatn, A. 2021. 'Institutional context, political-value orientation and public attitudes towards climate policies: A qualitative follow-up study of an experiment', Environmental Values 30: 43-63. Crossref

Barry, J. 1994. 'The limits of the shallow and the deep: Green politics, philosophy, and praxis', Environmental Politics 3: 369-394. Crossref

Baskin, J. 2015. 'Paradigm dressed as epoch: The ideology of the Anthropocene', Environmental Values 24: 9-29. Crossref

Conty, A.F. 2021. 'Religion in the age of the Anthropocene', Environmental Values 30: 215-234. Crossref

Dicks, H. 2019. 'Being like Gaia: Biomimicry and ecological ethics', Environmental Values 28: 601-620. Crossref

Korhonen, J., A. Honkasalo, and J. Seppälä. 2018. 'Circular Economy: The concept and its limitations', Ecological Economics 143: 37-46. Crossref

Kortetmäki, T. 2019. 'The reification of non-human nature', Environmental Values 28: 489-506. Crossref

Nordgren, A. 2012. 'Meat and global warming: Impact models, mitigation approaches and ethical aspects', Environmental Values 21: 437-457. Crossref

Paterson, M. 2000. 'Car culture and global environmental politics', Review of International Studies 26: 253-270. Crossref

Paterson, M. 2007. Automobile Politics: Ecology and Cultural Political Economy. Cambridge: Cambridge University Press.

Pollan, M. 2006. The Omnivore's Dilemma: A Natural History of Four Meals. New York: Penguin Books.

Schoppek, D.E. 2020. 'How far is degrowth a really revolutionary counter movement to neoliberalism?' Environmental Values 29: 131-151. Crossref

Spash, C. L. 2020a. 'Days of decision', Environmental Values 29: 387-396. Crossref

Spash, C. L. 2020b "“The economy” as if people mattered: Revisiting critiques of economic growth in a time of crisis', Globalizations, 1-18. Crossref

Szaj, P. 2021. 'Hermeneutics at the time of the Anthropocene: The case of Hans-Georg Gadamer', Environmental Values 30: 235-254. Crossref

Takle, M. 2021. 'The Norwegian Petroleum Fund: Savings for future generations?' Environmental Values 30: 147-167. Crossref

Vaughan, H. 2021. 'A Green intervention in media production culture studies: Environmental values, political economy and mobile production', Environmental Values 30: 193-214. Crossref

Veraart, R. and V. Blok. 2021. 'Towards a philosophy of a bio-based economy: A Levinassian perspective on the relations between economic and ecological systems', Environmental Values 30: 169-192. Crossref

Zwart, H. 2019. 'What is mimicked by biomimicry? Synthetic cells as exemplifications of the threefold biomimicry paradox', Environmental Values 28: 527-549. Crossref 